\title{
FLOWER SCENT ANALYSIS OF Encyclia vespa (VELL.) DRESSLER \& G. E. POLLARD AND E. fragrans (SW.) LEMÉE
}

\author{
Maria das Graças B. ZOGHBI*, Eloisa Helena A. ANDRADE*, \\ Manoela Fernandes F. da SILVA*, José Guilherme S. MAIA**
}

\begin{abstract}
RESUMO - Os constituintes voláteis obtidos dos extratos pentânicos das flores de Encyclia vespa e E. fragrans através de destilação-extração simultânea foram analisados por CG/EM. Os principais componentes voláteis identificados nas flores de $E$. vespa foram terpinen-4-ol (20,3\%), verbenona $(14,8 \%)$, trans-verbenol $(13,6 \%)$ e $\alpha$-pineno $(11,8 \%)$. Os principais voláteis das flores de $E$. fragrans foram terpinen-4-ol $(18,3 \%),(2 Z, 6 E)$-farnesol $(15,4 \%)$ e trans-verbenol $(10,2 \%)$.
\end{abstract}

Palavras-chave: Encyclia vespa, Encyclia fragrans, Orchidaceae, voláteis de flores, terpinen-4ol, verbenona, trans-verbenol, $(2 Z, 6 E)$-farnesol, $\alpha$-pineno.

Análise do Aroma das Flores de Encyclia vespa (Vell.) Dressler \& G. E. Pollard and E. fragrans (Sw.) Lemée

ABSTRACT - The volatile constituents obtained from the pentane extract, using simultaneous distillation-extraction of the flowers of Encyclia vespa and E. fragrans were analysed by $\mathrm{GC} /$ MS. The main volatile components identified in the flowers of $E$. vespa were terpinen-4-ol $(20.3 \%)$, verbenone $(14.8 \%)$, trans-verbenol $(13.6 \%)$ and $\alpha$-pinene $(11.8 \%)$. The major volatiles of the flowers of $E$. fragrans were terpinen-4-ol $(18.3 \%),(2 Z, 6 E)$-farnesol $(15.4 \%)$ and transverbenol $(10.2 \%)$.

Key-Word: Encyclia vespa, Encyclia fragrans, Orchidaceae, flower volatiles, terpinen-4-ol, verbenone, trans-verbenol, $(2 Z, 6 E)$-farnesol, $\alpha$-pinene.

\section{INTRODUCTION}

The genus Encyclia Hooker includes some species with fragrant flowers which often grow in large numbers, making these plants very attractive and well worth cultivating. The color of the flowers is highly variable among the species, as well as their size and fragrance. The genus comprise almost 150 species, located mainly in Mexico and the West Indies with a scattering of species from Florida to Tropical Northern South America (Sheehan \& Sheehan, 1994). The species analysed are epiphytes from various Amazonian ecosystems (Werkhoven, 1986; Silva \& Silva, 1998). The scents and chemical compositions were reported by Kaiser (Kaiser, 1993) for some 160 species of orchids, including five species of Encyclia. The species E. adenocarpa, an epiphyte from Guatemala, gives off a particularly ionone-rich scent due the presence of $\beta$-ionone and derivatives. The scent of E. baculus, a species distributed from Mexico to Colombia, is dominated by an "aromatic spicy-floral" accord, consisting of aromatic esters, phenols, vanilline and indole, complemented by a distinctive herba-

Museu Paraense Emílio Goeldi, Departamento de Botânica, CP 399, 66040-170 Belém, PA, Brazil Universidade Federal do Pará, Departamento de Química, 66075-900 Belém, PA, Brazil 
ceous and straw-like note. The scent of E. citrina, growing in the mountainous regions of Mexico, is based on an accord produced by the interaction of large quantities of ipsdienol and ipsdienone, together with neral and geranial. The species E. glumacea, a native of Brazil, has its scent based on linalool and anisaldehyde. Kaiser has described also the aromatic-floral scent of E. fragrans, growing in the St Gallen Botanical Gardens, in Switzerland, that harmonizes with a top note reminiscent of passion fruit and mango, while an attrative contrast is formed by a rather astringent note that is reminiscent of tea roses. This latter aspect is produced primarily by the compound 3,5-dimethoxytoluene. This paper relates the volatiles obtained from the flowers of Encyclia fragrans (Sw.) Lemée (Syn: Epidendrum fragrans Sw., E. cochleatum Curtiss) and Encyclia vespa (Vell.) Dressler \& G. E. Pollard (Syn: Epidendrum vespa Vell., E. baculibulbum Schltr., E. christi Rchb. f., E. coriaceum Focke, E. coriaceum Parker ex Hook., E. crassilabium Poepp. \& Endl., E. feddeanum Kraenzl., E. leopardinum Rchb. f., E. longipes Rchb. f., E. pachysepalum Klotzsch, E. phabdobulbon Schltr., E. phopalobulbon Schltr., E. saccharatum Kraenzl., E. tigrinum Linden ex Lindl., $E$. variegatum Hook., E. variegatum var. crassilabium (Poepp. \& Endl.) Lindll., E. vespa Vell.).

\section{MATERIAL AND METHODS}

The flowers of $E$. vespa and $E$. fragrans were obtained from private collection of Mr Ferdinando Cardoso do Nascimento, of Águas Lindas, Municipal- ity of Ananindeua, State of Pará. The species were identified by Mr João Batista da Silva, a specialist in Amazon Orchids. Fresh flowers of $E$. vespa $(4.6 \mathrm{~g})$ and $E$. fragrans $(10.4 \mathrm{~g})$ were subjected to simultaneous distillation-extraction for 3 hours using a Chrompak micro-distillation extractor and $n$-pentane $(2 \mathrm{~mL})$ as organic phase. The volatile concentrates were analysed on a GC/MS Finnigan system (gas chromatograph Varian model 3400, mass spectrometer Finnigan model INCOS-XL) under the following conditions: column: DB-5 fused silica (30 $\mathrm{m} \mathrm{x}$ $0.25 \mathrm{~mm} ; 0.25 \mu \mathrm{m}$ film thickness); carrier gas: helium, adjusted to a linear velocity of $32 \mathrm{~cm} / \mathrm{sec}$ (measured at $100^{\circ} \mathrm{C}$ ); temperature programmed at $60^{\circ}-240^{\circ} \mathrm{C}\left(3^{\circ} \mathrm{Cl}\right.$ $\mathrm{min})$; injection type: splitless $(1 \mu \mathrm{L}$ of the pentane solution); mass spectra: $70 \mathrm{eV}$ (in EI mode). Individual components were identified by comparison of both mass spectra and their GC retention data with those of authentic compounds previously analysed and stored in the data system. Others identification were made by comparison of mass spectra with those in the data system libraries and cited on the literature (Adams, 1995; Jennings \& Shibamoto, 1980). The retention indices were calculated for all volatiles constituents using homologous series of $n$-alkanes on a DB-5 column.

\section{DISCUSSION}

The ion-chromatogram of the volatile concentrates of the flowers of $E$. vespa and $E$. fragrans are shown in Figures 1-2. The quantitative data were obtained by eletronic integration of the TIC peak area. The compounds identified in the volatile concentrates 
are listed in Table 1. It can be seen that the most abundant class of compounds found in the volatile concentrates of both species were terpenoids. The main terpenescomponents identified in the flowers of E. vespa were terpinen-4-ol $(20.3 \%)$, verbenone $(14.8 \%)$, trans-verbenol $(13.6 \%), \alpha$ pinene $(11.8 \%)$ and linalool (8.9\%). In the flowers of $E$. fragrans, the main terpenes identified were terpinen-4-ol (18.3\%), (2Z,6E)-farnesol (15.4\%) and trans-verbenol $(10.2 \%)$. Verbenone, $\alpha$-pinene and linalool could not be identified in the flowers of $E$. fragrans, nor do the farnesol isomers occur in the flowers of E. vespa. The aliphatic hydrocarbons heneicosane $(8.5 \%)$, eicosane $(4.6 \%)$, docosane $(1.0 \%)$, hexadecane $(0.9 \%)$ and heptadecane $(0.7 \%)$ were detected in the flowers of $E$. fragrans while the esters methyl $p$-aniysate $(3.4 \%)$, methyl benzoate $(2.9 \%)$, benzyl benzoate $(0.8 \%)$ and hexadecyl acetate $(0.6 \%)$ were found in the flowers of $E$. vespa. A previous report on the chemical composition of the flowers of $E$. fragransis showed different results (Kaiser, 1993); the main constituents identified in that report were $(E)$ ocimene $(32.0 \%)$, $3,5-$ dimethoxytoluene $(10.1 \%)$, methyl (E)-cinnamate $(9.2 \%)$ and hydroquinone dimethyl ether $(8.8 \%)$. The composition of floral scents is highly dependent on its degree of maturity and on endogenous and exogenous factors (Kaiser, 1993). The orchid family is particularly rich in species with a high degree of time-dependency in their scent emanation. Concerning the experimental and biological aspects of the collection and analysis of flower scents, it should be pointed out that the composition of the scent of a defined species can vary from plant to plant, particularly in the case of actual chemotypes. Indeed, the sample analysed here show an aromatic-floral accord with a little top note of passion fruit and mango, but without the reminiscent note of tea roses produced by the compound 3,5-dimethoxytoluene, present only in the material studied by Kaiser.

\section{ACKNOWLEDGMENTS}

This work was supported by the Programa Piloto para a Proteção das Florestas Tropicais (sponsored by G-7). The authors would like to thank to $\mathrm{Mr}$ João Fernandes da Silva for plant identification and to Mr Ferdinando Cardoso do Nascimento for plant collection.

\section{Literature cited}

Adams, R.P. 1995. Identification of Essential Oil Components by Gas Chromatography/ Mass Spectrometry. Allured Publishing Corporation, Illinois, 469pp.

Jennings, W.; Shibamoto, T, 1980. Qualitative Analysis of Flavor and Fragrance Volatiles by Glass Capillary Gas Chromatography, Academic Press, New York, 472pp.

Kaiser, R. 1993. The Scents of Orchids: Olfactory and Chemical Investigations, Givaudan-Roure, Dübendorf, 259pp.

Sheehan, T.; Sheehan, M. 1994. An Illustrated Survey of Orchid Genera, University Press, Cambridge, 421pp.

Silva, J.B.F. da; Silva, M.F.F.da 1998. 


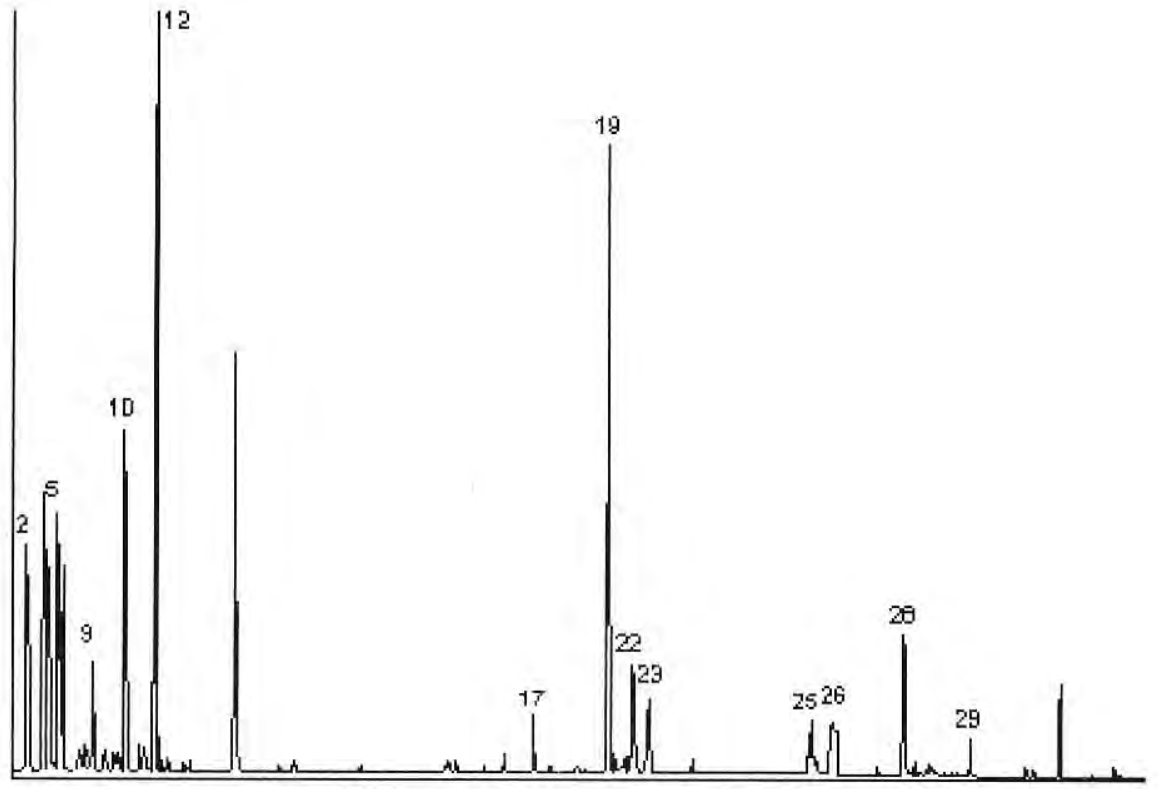

Figure 1. Ion-chromatogram of the volatile constituents of the flowers of $E$. vespa.

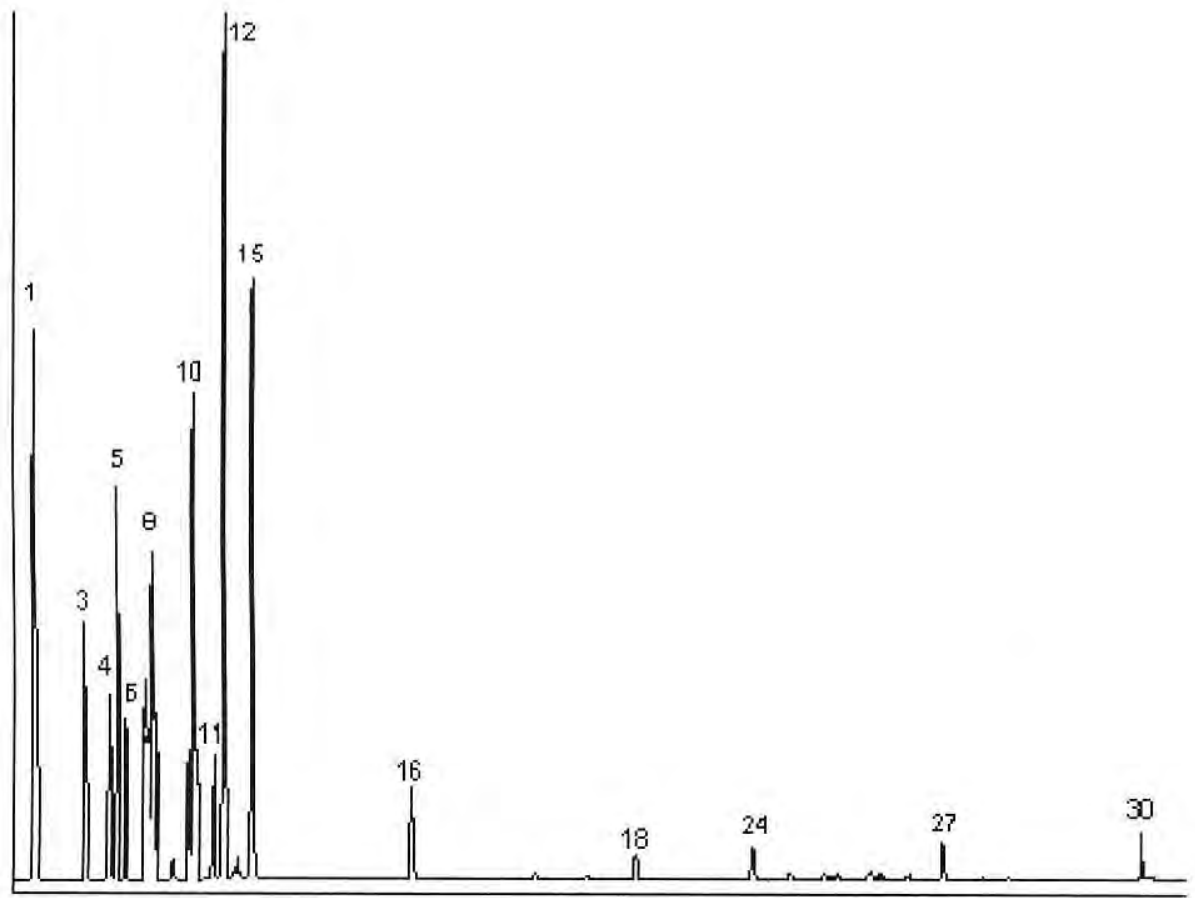

Figure 2. Ion-chromatogram of the volatile constituents of the flowers of E. fragrans. 
Table 1. Volatile constituents (\%) of the flowers scents of Encyclia vespa and E. fragrans

\begin{tabular}{|c|c|c|c|c|}
\hline No. & Constituents & $R I^{*}$ & E. vespa & E. fragrans \\
\hline 01 & $\alpha$-Pinene & 936 & 11.8 & \\
\hline 02 & $\Delta^{3}$-Carene & 1009 & & 3.2 \\
\hline 03 & $\alpha$-Terpinene & 1019 & 4.3 & \\
\hline 04 & (E)- $\beta$-Ocimene & 1050 & 2.2 & \\
\hline 05 & $\gamma$-Terpinene & 1061 & 7.5 & 4.8 \\
\hline 06 & cis-Sabinene hydrate & 1069 & 2.0 & \\
\hline 07 & Methyl benzoate & 1088 & 2.9 & \\
\hline 08 & Linalool & 1098 & 8.9 & \\
\hline 09 & Nonanal & 1099 & & 2.6 \\
\hline 10 & trans-Verbenol & 1141 & 13.6 & 10.2 \\
\hline 11 & $p$-Mentha-1,5-dien-8-ol & 1163 & 2.0 & \\
\hline 12 & Terpinen-4-ol & 1175 & 20.3 & 18.3 \\
\hline 13 & p-Cymen-8-ol & 1181 & 1.0 & \\
\hline 14 & $\alpha$-Terpineol & 1188 & 1.9 & \\
\hline 15 & Verbenone & 1205 & 14.8 & \\
\hline 16 & Methyl $p$-anisate & 1370 & 3.4 & \\
\hline 17 & Hexadecane & 1600 & & 0.9 \\
\hline 18 & Dillapiole & 1620 & 1.1 & \\
\hline 19 & $(2 Z, 6 E)$-Farnesol & 1693 & & 15.4 \\
\hline 20 & Heptadecane & 1700 & & 0.7 \\
\hline 21 & $(Z, Z)$-Farnesol & 1713 & & 0.8 \\
\hline 22 & $(E, E)$-Farnesol & 1721 & & 2.9 \\
\hline 23 & $(E, Z)$-Farnesol & 1740 & & 1.2 \\
\hline 24 & Benzyl benzoate & 1759 & 0.8 & \\
\hline 25 & Palmitic acid & 1957 & & 1.3 \\
\hline 26 & Eicosane & 2000 & & 4.6 \\
\hline 27 & Hexadecyl acetate & 2010 & 0.6 & \\
\hline 28 & Heneicosane & 2100 & & 8.5 \\
\hline 29 & Docosane & 2200 & & 1.0 \\
\hline 30 & Tricosane & 2302 & 1.1 & \\
\hline
\end{tabular}

${ }^{*} \mathrm{RI}=$ Retention lindex on DB-5 
Orquídeas Nativas da Amazônia Brasileira: Gênero Catasetum L. C. Rich. ex Kunth. Belém, MPEG, 121p.

Werkhoven, M.C.M. 1986. Orchids of

Suriname, VACO N. V., Suriname, 256pp. 